\title{
CrimRxiv
}

\section{Child Execution in Iran: Furthering Our Understanding of Child Execution as a Form of Structural Violence}

Nadia Aghtaie, Jo Staines

Published on: Mar 03, 2022

DOI: $10.21428 / \mathrm{cb} 6 \mathrm{ab} 371.8 f 915 \mathrm{c} 96$

License: Creative Commons Attribution 4.0 International License (CC-BY 4.0). 
